\title{
Comparative analysis of national and regional models of the silver economy in the European Union
}

\author{
By ANDRZEJ KLIMCZUK*
}

\begin{abstract}
The approach to analysing population ageing and its impacts on the economy has evolved in recent years. There is increasing interest in the development and use of products and services related to gerontechnology as well as other social innovations that may be considered as central parts of the "silver economy." However, the concept of silver economy is still being formed and requires detailed research. This article proposes a typology of models of the silver economy in the European Union (EU) at the national and regional levels. This typology was created by comparing the Active Ageing Index to the typology of varieties and cultures of capitalism and typology of the welfare states. Practical recommendations for institutions of the EU and directions for further research are discussed.
\end{abstract}

Keywords: active ageing index, regional development, silver economy, varieties/cultures of capitalism, welfare state.

*Andrzej Klimczuk, Warsaw School of Economics, Warsaw, Poland 
International Journal of Ageing and Later Life

\section{Introduction}

Population ageing is characterised by an increase in the length of human life, which favours the development of goods and services for older consumers and ageing societies. Increasing interest in this context has led to the concept of the "silver economy." The silver economy is usually broadly described as "all types of goods and services for older adults and an ageing population, including extending the working life, volunteerism, and active citizenship of older people" (Klimczuk 2015: 77) or in a narrower sense a combination of suitable conditions of supply of goods and services and the growing purchasing power of older consumers (European Commission 2007: 96). Age-friendly products and services associated with the use of gerontechnology and social innovations may be considered as central parts of the silver economy. Age-friendly solutions are complementary to the United Nations' (UN) concept of "society for all ages" and the implementation of the Madrid International Plan of Action on Ageing (MIPAA). This document, which was adopted in 2002, is a set of obligations and guidelines for strategic management in the area of social policy towards old age as well as social policy for older adults (also called together as the ageing policy or public policy on ageing) in each member state of the UN (cf. Błędowski 2012; Ervik \& Lindén 2013; Szatur-Jaworska 2006).

The Active Ageing Index 2012 and 2014 (AAI) of the United Nations Economic Commission for Europe and the European Commission is a practical tool to monitor the implementation of the MIPAA and it clearly shows that population ageing is not only differentiated in demographic terms but also in the socio-economic fields, which are crucial to the development of the silver economy on national and regional levels. However, there is a need to deepen the explanations regarding the clustering of countries in the domain-specific indices to support the development of national and regional economies that will meet the needs of ageing populations.

The central thesis of this article is that the Active Ageing Index (AAI) due to the comparison with the clustering of countries in (1) typologies of varieties and cultures of capitalism and (2) typologies of welfare states may be used to explain the emerging differentiation of models of the silver economy in the countries of the European Union (EU). The methodology 
Comparative analysis of national and regional models

of this article is based on a literature review and case studies. The analysis focused on the identification of national and regional factors relevant to the development of the silver economy together with outcomes of active ageing.

The first part of the article includes the literature review of theoretical concepts associated with the silver economy and the implementation of the $\mathrm{UN}$ and the EU strategies for an ageing population. The second part focuses on comparisons of the AAI and its domain-specific indices for different clustering of countries. The third part includes selected findings of the in-depth analysis of the selected cases of regional models of the silver economy.

Conclusions contain practical recommendations for institutions engaged in ageing policy and suggestions for further research.

\section{Relations between the active ageing policy and the silver economy}

According to the World Health Organization (2002: 12), active ageing may be defined as "the process of optimising opportunities for health, participation and security in order to enhance the quality of life as people age." This approach, in particular, draws attention to the life course perspective on ageing, diversity of older adults, and a holistic approach to determinants of ageing including: crosscutting factors of culture and gender; health and social system; behavioural factors; personal factors; physical environment; social environment; and economic factors (WHO 2002: 19-32).

Active ageing also draws particular attention to the need for policies to reduce healthcare and social security costs associated with noncommunicable diseases (NCDs) that are more common among older people (WHO 2002: 14, 42). Many NCDs may be avoided or delayed by health promotion, prevention of chronic diseases, promotion of healthy lifestyles and safety at work that reduces the risk of disability and promotion of independent living and "ageing in place." All these areas require the use of appropriate products and services for older adults and ageing societies.

Moreover, technological development allows wider use of solutions that will partially complement labour shortages associated with demographic change (population ageing and population decline) through the growth of labour productivity and replacement of many physical activities with 
International Journal of Ageing and Later Life

machines and robots (Ervik 2009). However, not including these effects can lead to a new form of digital divide in the EU called the "robotics divide."

This brings us to the concept of the "silver economy," which is often seen in the narrow sense as the "silver market" that includes goods and services for older adults and solutions for ageing workers. However, such an approach may lead only to changes in marketing (mainly to create the socalled "age brands") while there is a need to focus also on reducing ageism and using age-friendly solutions in public spaces and homes. Thus, the wider approach to the silver economy also includes education, research and development (R\&D), a cross-sector set of goods and services from already existing sectors, and career opportunities in the silver industries (European Commission 2007: 96). The silver industries or segments of the silver market include health care; smart living, housing adaptations and supported living services (increasingly based on information and communication technologies, or ICTs); education and culture; ICTs and media; service robotics; mobility; recreation; travel; fitness and wellness; clothing and fashion; care services; insurances; and financial services (Enste et al. 2008: 330-331; Moody and Sasser 2012: 464).

Gerontechnologies and social innovations can be considered as essential components of the silver economy. The first term refers to the study of technology, products and services dedicated to older people, designed to assist them in almost every aspect of life, in particular, health and selfesteem, housing and daily living, mobility and transport, communication and governance, and work and leisure (Burdick 2007: 627-629) - designing electronic aids for daily living such as telework solutions, detectors, alarms, sensors, equipment to overcome impairments in hearing and sense of smell and bathroom systems. Social innovation refers to new strategies, concepts, products, services and organisational forms aimed at satisfying the needs that arise, in particular, on the edges of various sectors of the social system (O'Sullivan et al. 2010). Examples include innovations emerging at the interface between cooperation and competition in the public sector, commercial sector, the social economy sector or the informal sector. Such innovations have social objectives, social means and generate new social relations and co-operative ties. Examples of such innovations include the use of new technologies in a creative way "for and by" older people; new models of care, including combinations of formal and 
Comparative analysis of national and regional models

informal support; age-friendly environments; and mobilising trusted networks (circles of support, self-help groups).

However, various barriers to the development of the silver economy at national and regional levels can be observed (Klimczuk 2011). For example, the small interest of market entities in these concepts in some regions, perception of the silver economy as goods for wealthy older people, unfavourable patterns of consumption by seniors and low attractiveness of some regions for older migrants and travellers. Another barrier may be the little interest of business entities in the development and implementation of the silver economy in some peripheral regions such as rural regions and borderline regions. Moreover, the focus of companies on goods and services only for the affluent older adults might also be an obstacle. The detrimental consumption patterns of some older adults might be an issue, too (e.g. the orientation on products that meet basic needs and health, distrust towards new solutions and technologies). In addition, some regions may guide the development of the silver economy in attracting older migrants and tourists, but this strategy may not bring the expected effects of the development due to, for example, their low attractiveness in comparison with metropolitan areas or deficiencies in social infrastructure.

The ageing policy of the EU already includes a number of intervention areas and focuses on mainstreaming ageing (European Commission 2005, $2009,2011,2012)$. These activities are oriented to consider ageing in specific policies such as employment policy, equal opportunities policy, innovation policy, scientific policy and lifelong learning policy. However, the development of the silver economy requires an increase in the scope of coordination of policies, cooperation between top-down and bottom-up initiatives (see Enste et al. 2008: 330; Ferry et al. 2006: 31-33, 80-90; “SEN@ER" network 2014), the cohesion of strategic documents, a multilevel governance, the development of statistical indicators, integration and reorganisation of public services in co-production with citizens and the creation of structures and forms of dialogue between communities and administration (Katsarova 2008). This article suggests that the regional silver economies may also be associated with smart specialisation strategies within cohesion policy 2014-2020 because in some regions there are already strong development centres of gerontechnologies and social innovations for 
International Journal of Ageing and Later Life

ageing societies (cf. Eatock 2015; European Commission 2015a, 2015b; Foray et al. 2012).

The AAI in the context of varieties of capitalism and typologies of welfare states

The AAI includes comparisons between the 28 EU member states, including indicators divided into two dimensions and four domains that are further subdivided by gender (Zaidi et al. 2013: 6). The first dimension is "actual experiences of active ageing" (domains: employment; participation in society; independent, healthy and secure living). The second dimension and domain is "capacity and enabling environment for active ageing" that is related to Amartya Sen's (2009) notion of capabilities understood as opportunities and empowerments to improve well-being and quality of life. Regarding active ageing, the second dimension and domain were defined by measuring of human assets (e.g. remaining life expectancy), health capital (mental well-being indicators) and human capital understood as educational attainment indicators The countries performing the worst on the overall AAI are sometimes better in some domains than in others. For example, Hungary has one of the lowest overall ranks but is performing relatively well in the field of independent living. In addition, the indices for all three domains of actual experiences of active ageing are positively correlated with the index of the capacity and enabling the environment for active ageing (Zaidi et al. 2013: 26, 29, 32). In other words, countries that are better prepared for ageing in terms of infrastructure, human capital and social capital are also better at solving the challenges associated with the ageing of their populations. Moreover, a positive correlation of the AAI with gross domestic product (GDP) per capita was noted, which suggests that the countries with relatively higher standards-of-living are generating better capacity and enabling environment for active ageing (Zaidi et al. 2013: 21).

However, the AAI in proposed form only partially allows us to explain the differences between the emerging silver economies in the countries of the EU because it does not include indicators related to the consumption, production, and R\&D of goods and services for ageing societies. Thus, it can be extended through the adaptation of, for example, elements of typologies of welfare states and varieties of capitalism. A well-known 
concept of different welfare regimes was proposed by Esping-Andersen (1990) and includes the decommodification index and impact of benefits and social services on social stratification. This theory explains that countries with a social-democratic regime, such as the Nordic countries, tend to have a high degree of decommodification (i.e. more opportunities for a person to maintain a livelihood without reliance on the market. This does not mean that private providers of care and social services are not present or that their quality of care is better or worse than that provided by state entities or NGOs), universal care and nursing services provided by public entities, high wage replacement by social benefits, full employment policy and the firm position of labour unions (cf. Lindbom 2001). In a conservative corporatist regime, such as in Austria, France, Germany, Italy and Japan, the state supports the family; social security depends on the position of individuals in the labour market; and social care insurance and nursing care services are primarily delivered by informal carers, NGOs and local communities. Public administration intervenes only when indicated entities are not in a position to cope with the problems (principle of subsidiarity). The last group of countries (e.g. the United Kingdom and the United States) represents a liberal regime, which is characterised by individualism in the field of social security, low decommodification and social benefits, benefits based on income, widespread commercialisation of care and nursing services, competition between different suppliers and a small role of labour unions.

Esping-Andersen's typology has been repeatedly tested, criticised and modified by many scholars (Arts \& Gelissen 2006). The criticisms were related mainly to (1) the non-systematic inclusion of the Mediterranean countries, (2) description of the Antipodean welfare states as liberal regimes and (3) simplification or avoidance of the gender dimension in social policy. This article will refer to the modification of Esping-Andersen's typology proposed by Kazepov (2010: 52-63), who extended this typology by two types of welfare states. Kazepov's theory focuses on "rescaling" and co-governance of social policy that takes into account not only the decentralisation of services in a way that the focus is on the transfer of service implementation through outsourcing by the entities of the central level of state to local authorities but also to make it even more targeted towards the development of mixed forms of social welfare 
International Journal of Ageing and Later Life

(welfare mix) at the regional and local levels, which means the implementation of social services in the form of various cross-sector partnerships. The first, familistic system (among others, Spain and Italy), focuses on fewer resources that are targeted at family policies and overload of the family in social caring responsibilities, the gender segmentation in the labour market, local differentiation of particularistic interests and different forms of governance and weak prevention of poverty. The second, welfare system in transition countries, refers to an emerging model in most Central European and East European countries. The reforms are taken here in the context of financial constraints and with ambivalent consequences. Some countries focus on privatisation (e.g. in pension reforms) while others invest in the coordinated market and social policies. In addition, there were significant reforms of the territorial organisation oriented to move away from central regulation towards more decentralised levels.

Table 1 covers comparison of selected countries concerning the AAI and typologies of welfare states. This table shows that social-democratic regimes (e.g. Sweden) ${ }^{1}$ and liberal regimes (the United Kingdom) cope relatively better with the population ageing than corporative regimes (France), familistic regimes (Italy) and regimes in transition (Poland). Deepening explanations concerning the differences between these systems is possible by analysis of the achievements and challenges of selected countries representing different models of welfare states presented in the Synthesis Report on the implementation of the MIPAA in the United Nations Economic Commission for Europe (UNECE) Region (2012). Most of the liberal, social-democratic and corporative states achieved the MIPAA commitments 1 (mainstreaming ageing), 4 (adjust social protection systems to demographic changes) and 7 (ensure the quality of life at all ages and maintain an independent living). In the case of challenges, socio-democratic states tend to have problems with commitments 2 (ensure full

\footnotetext{
${ }^{1}$ At this point, we need to highlight that the term "social-democratic regimes" is still being used although the social-democratic political parties are no longer dominating the parliaments in the Nordic countries in recent years. Moreover, a variety of reforms related to privatisation and marketisation of social benefits and services have been introduced, that are sometimes described as "dismantling" or "retrenchment" of the social-democratic welfare model (Lavelle 2008: 143-168; Lindbom 2001).
} 
Comparative analysis of national and regional models

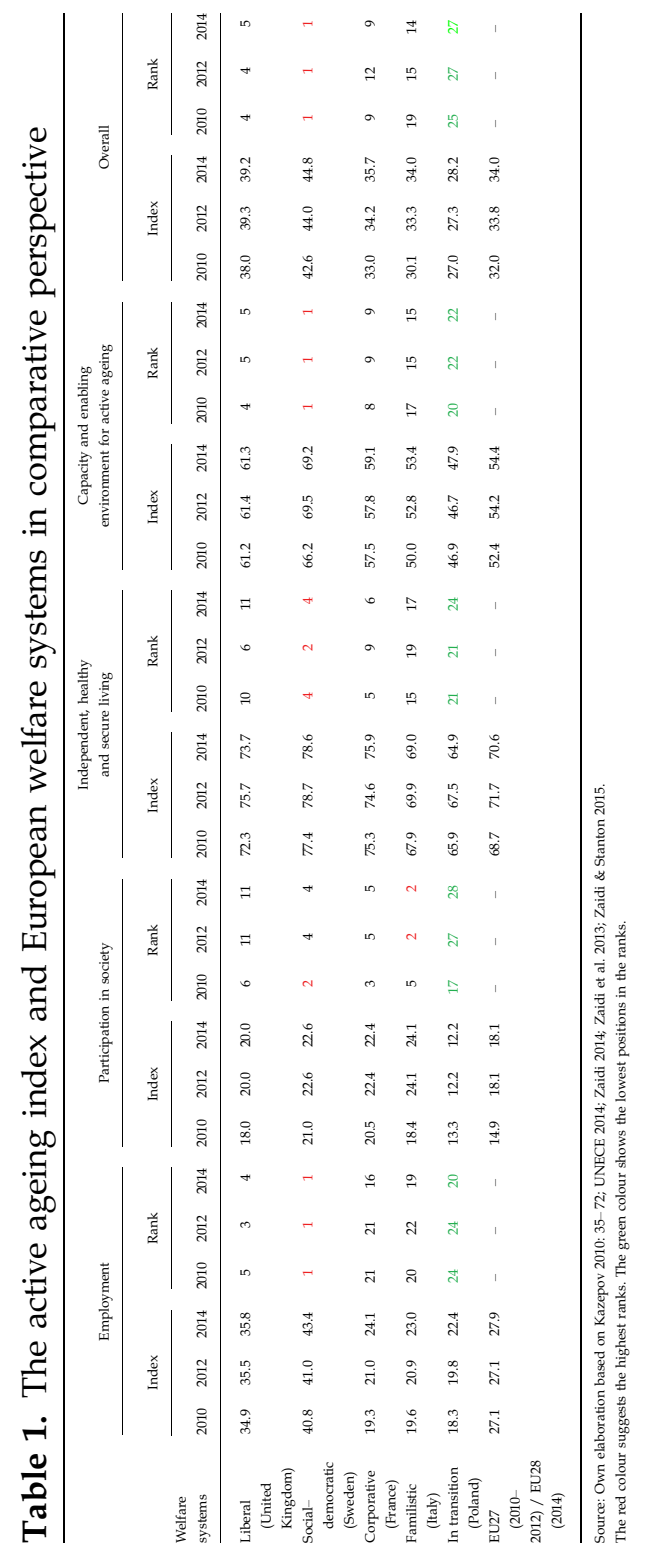


International Journal of Ageing and Later Life

integration and participation of older persons) and 7 while corporatist regimes with commitments 4 and 7. There is no definite pattern of challenges in liberal states. Familistic regimes tend to achieve commitments 4 and 5 (an adaptation of labour markets to population ageing) but commitment 7 is a challenge. Regimes in transition tend to treat commitment 1 as an achievement while 4 and 7 are challenges. A summary of these considerations is included in Table 2. Thus, it can be stated that the transition countries have some similarities to the countries of the conservative-corporate regime, which can be explained by geographical proximity and perhaps by the related diffusion and adaptation of similar regulations and practices. This resemblance seems to confirm a similar weakness in the AAI of the conservative-corporate systems in terms of the effective promotion of employment among older adults.

Typologies of welfare states in conjunction with the AAI may explain the differences between potential models of the silver economy in particular with regard to social benefits and services. It is reasonable, however, also to take into account the differences in socio-cultural factors that affect the practice of business in individual countries and thereby their economic policies. In reference to the theory of Peter A. Hall \& David W. Soskice (2001), we may narrow down our description of the emerging models to three models of the silver economy in the EU. It should be emphasised that the typology of Hall and Soskice, similar to the cited typologies of Esping-Andersen and Kazepov, highlights the impact of the level of individualism and activities of trade unions on the differences between the countries of the EU.

Liberal welfare regimes (not only countries from Europe but also Australia and the United States) correspond to the liberal silver economies, which are characterised by competitive market arrangements and interfirm relations; equilibrium achieved through the demand/supply and hierarchy; direct product competition; complete and formal contracting; freer movement of inputs; full-time employment in case of general skill and short-term employment in specific skills; wage bargain at the firm level; focus on formal education from high schools and colleges; low rate of unionisation; unequal income distribution; radical innovation; comparative advantages in high-tech and service; and policies aimed at deregulation, antitrust and tax breaks. 
Comparative analysis of national and regional models

Table 2. European welfare systems and main achievements and main challenges in the implementation of the regional implementation strategy for the Madrid International Plan of Action on Ageing (MIPAA/RIS) 2002

\begin{tabular}{|c|c|c|}
\hline $\begin{array}{l}\text { The ten commitments of the } \\
\text { MIPAA/RIS } 2002\end{array}$ & $\begin{array}{l}\text { Main achievement } \\
\text { in welfare systems }\end{array}$ & $\begin{array}{c}\text { Main challenge } \\
\text { in welfare systems }\end{array}$ \\
\hline $\begin{array}{l}\text { 1. To mainstream ageing in all } \\
\text { policy fields with the aim } \\
\text { of bringing societies and } \\
\text { economies into harmony } \\
\text { with demographic change to } \\
\text { achieve a society for all ages }\end{array}$ & $\begin{array}{l}\text { - Liberal } \\
\text { (United Kingdom) } \\
\text { - Social-democratic } \\
\text { (Sweden) } \\
\text { - Corporative (France) } \\
\text { - In Transition (Poland) }\end{array}$ & $\begin{array}{l}\text { - None of the selected } \\
\text { welfare states }\end{array}$ \\
\hline $\begin{array}{l}\text { 2. To ensure full integration and } \\
\text { participation of older persons } \\
\text { in society }\end{array}$ & $\begin{array}{l}\text { - Liberal } \\
\text { (United Kingdom) } \\
\text { - In Transition (Poland) }\end{array}$ & $\begin{array}{l}\text { - Social-democratic } \\
\text { (Sweden) }\end{array}$ \\
\hline $\begin{array}{l}\text { 3. To promote equitable and } \\
\text { sustainable economic growth in } \\
\text { response to population ageing }\end{array}$ & - Familistic (Italy) & $\begin{array}{l}\text { - None of the selected } \\
\text { welfare states }\end{array}$ \\
\hline $\begin{array}{l}\text { 4. To adjust social protection } \\
\text { systems in response to } \\
\text { demographic changes and } \\
\text { their social and economic } \\
\text { consequences }\end{array}$ & $\begin{array}{l}\text { - Liberal } \\
\text { (United Kingdom) } \\
\text { - Social-democratic } \\
\quad \text { (Sweden) } \\
\text { - Corporative (France) } \\
\text { - Familistic (Italy) }\end{array}$ & $\begin{array}{l}\text { - Corporative (France) } \\
\text { - In Transition (Poland) }\end{array}$ \\
\hline $\begin{array}{l}\text { 5. To enable labour markets } \\
\text { to respond to the economic }\end{array}$ & - Familistic (Italy) & $\begin{array}{l}\text { - None of the selected } \\
\text { welfare states }\end{array}$ \\
\hline
\end{tabular}
and social consequences of population ageing

6. To promote lifelong learning - None of the selected - Familistic (Italy) and adapt the educational system in order to meet the changing economic, social and demographic conditions of life at all ages and maintain (Sweden) (Sweden) independent living including - Corporative (France) - Corporative (France) health and well-being - In Transition (Poland) - Familistic (Italy) - In Transition (Poland) 
International Journal of Ageing and Later Life

Table 2 (Continued)

\begin{tabular}{|c|c|c|}
\hline $\begin{array}{l}\text { The ten commitments of the } \\
\text { MIPAA/RIS } 2002\end{array}$ & $\begin{array}{l}\text { Main achievement } \\
\text { in welfare systems }\end{array}$ & $\begin{array}{l}\text { Main challenge } \\
\text { in welfare systems }\end{array}$ \\
\hline $\begin{array}{l}\text { 8. To mainstream a gender } \\
\text { approach in an ageing society }\end{array}$ & $\begin{array}{l}\text { - None of the selected } \\
\text { welfare states }\end{array}$ & $\begin{array}{l}\text { - None of the selected } \\
\text { welfare states }\end{array}$ \\
\hline $\begin{array}{l}\text { 9. To support families that provide } \\
\text { care for older persons and to } \\
\text { promote intergenerational and } \\
\text { intragenerational solidarity } \\
\text { among their members }\end{array}$ & $\begin{array}{l}\text { - None of the selected } \\
\text { welfare states }\end{array}$ & - Familistic (Italy) \\
\hline $\begin{array}{l}\text { 10. To promote the implementation } \\
\text { and follow-up of the Regional } \\
\text { Implementation Strategy } \\
\text { through regional cooperation }\end{array}$ & $\begin{array}{l}\text { - None of the selected } \\
\text { welfare states }\end{array}$ & $\begin{array}{l}\text { - None of the selected } \\
\text { welfare states }\end{array}$ \\
\hline
\end{tabular}

Source: Own elaboration based on UNECE 2012.

Most of the social-democratic and corporative regimes correspond to coordinated market economies (including Japan). Thus, we may assume that the silver economies in these countries are based more on non-market relations, equilibrium achieved through the strategic interaction between firms and other actors, collaborative inter-firm ties; differentiated and niche production; incomplete legal system and informal contracting, monitoring and sanctioning institutions, shorter hours of employment in case of specific skills and long term for immobile jobs, wage bargain at the industry level, apprenticeship imparting industry-specific skills, high rate of unionisation, equal income distribution, incremental innovation, comparative advantage in manufacturing and policies focused on encouraging collaboration of firms.

Hall and Soskice argue that the third model of capitalism may emerge in Mediterranean states. These countries are characterised by a large agrarian sector, the influence of non-market coordination in the sphere of corporate finance (entities of the social economy such as social enterprises, cooperative banks, cooperatives and non-government organisations engaged in business activities) and liberal arrangements in the labour relations. Thus, respectively, the third model of the silver economy would have features specific to the social economy, solutions based on the ideas of 
Comparative analysis of national and regional models

self-help and self-organisation and the related use of the strengths of rural areas (e.g. tourism, recreation, spa services and medical and geriatric rehabilitation).

However, it should be noted that Hall and Soskice in their typology do not take into account countries that are undergoing system transformation. The concept proposed by Andreas Nölke \& Arjan Vliegenthart (2009) may be used to supplement that gap. These scholars suggest that in transition countries, it is possible to observe the emergence of "dependent market economies" and thus the dependent silver economies characterised by dependence on intra-firm hierarchies within transnational enterprises, foreign direct investments and foreign-owned banks, control of transnational enterprises by headquarters, appeasement of skilled labour, companylevel collective agreements, limited expenditures for further qualification, intra-firm transfer within transnational enterprise and assembly platforms for semi-standardised industrial goods.

Deepening the analysis of the AAI results can also be based on the Charles Hampden-Turner \& Fons Trompenaars' (2000) model of national culture differences. This model is used in the context of management and includes seven dichotomous dimensions. In the dimension of "universalism-particularism," nearly all countries of the EU are characterised by the first dimension, which focuses on standardisation and rationalisation of activities, goods and services. In the dimension "individualism-communitarianism" we may assume that liberal and social-democratic regimes and regimes in transition underline individual behaviour while others focus on the group. In the dimension "specificitydiffuseness," the liberal and transition regimes tend to concentrate on analysing phenomena by collecting detailed information rather than the integration of knowledge. For example, focus on the development of various assistive technologies (nearly 40,000 products and services based on gerontechnology or related concepts are available in the United States market) rather than on few complex robotic solutions for older adults (such approach was promoted in Japan) (cf. AbleData 2016; Ministry of Education, Culture, Sports, Science and Technology, Japanese Government 2006). In the dimension "neutral-emotional," the liberal, socialdemocratic and corporative regimes tend to be neutral in expressing emotion, and business relationships are typically instrumental. Societies of 
International Journal of Ageing and Later Life

regimes in transition and familistic regimes are emotional, which is, for example, important in negotiations. The models of the silver economy in the EU countries may be divided into the dimension of "achieved-ascribed status": liberal and social-democratic regimes tend to focus more on achieving, while corporative and familistic regimes, and regimes in transition tend to have more hierarchies. In the dimension of "internal direction-outer direction," the EU societies tend to control the environment, for example, companies and governments are convinced that they can control nature and population trends as well as relations within and between social groups to achieve socio-economic goals (e.g. diversity and age management in organisations). The EU societies are different, in particular, from Japanese society, which seems to be more controlled by the environmental factors. For example, in Japanese society, there is a tendency to understand cooperation between people and nature, including in their attitudes towards demographic trends. There are also tendencies to avoid conflicts in organisations to achieve socio-economic goals (e.g. the seniority wage system). Broad consistency is also seen in the case of "sequential time-synchronous time" as societies of the EU tend to have a linear concept of time. This concept allows performing tasks in the shortest possible time. Meanwhile, in the extreme, there is a Japanese society where the recognition of the cyclical concept of time allows for long-term planning. We have to underline that although this model indicates the similarity of national cultures in the EU, it also distinguishes them from the United States and the Asian countries, in particular, from Japan where the silver market emerged in the 1970s (Coulmas 2008).

The above considerations allow us to conclude that in the EU we may observe the development of at least four models of the silver economy: liberal (liberal welfare regimes), coordinated (social-democratic and corporative), mixed/hybridised (familistic) and dependent (in transition). The main features of these models are included in Table 3. However, there may be more configurations at the regional level.

\section{Features of selected regional models of the silver economy}

This section focuses on the synthesis of diffused descriptions of selected cases of regional models of the silver economy in the EU. 
Comparative analysis of national and regional models

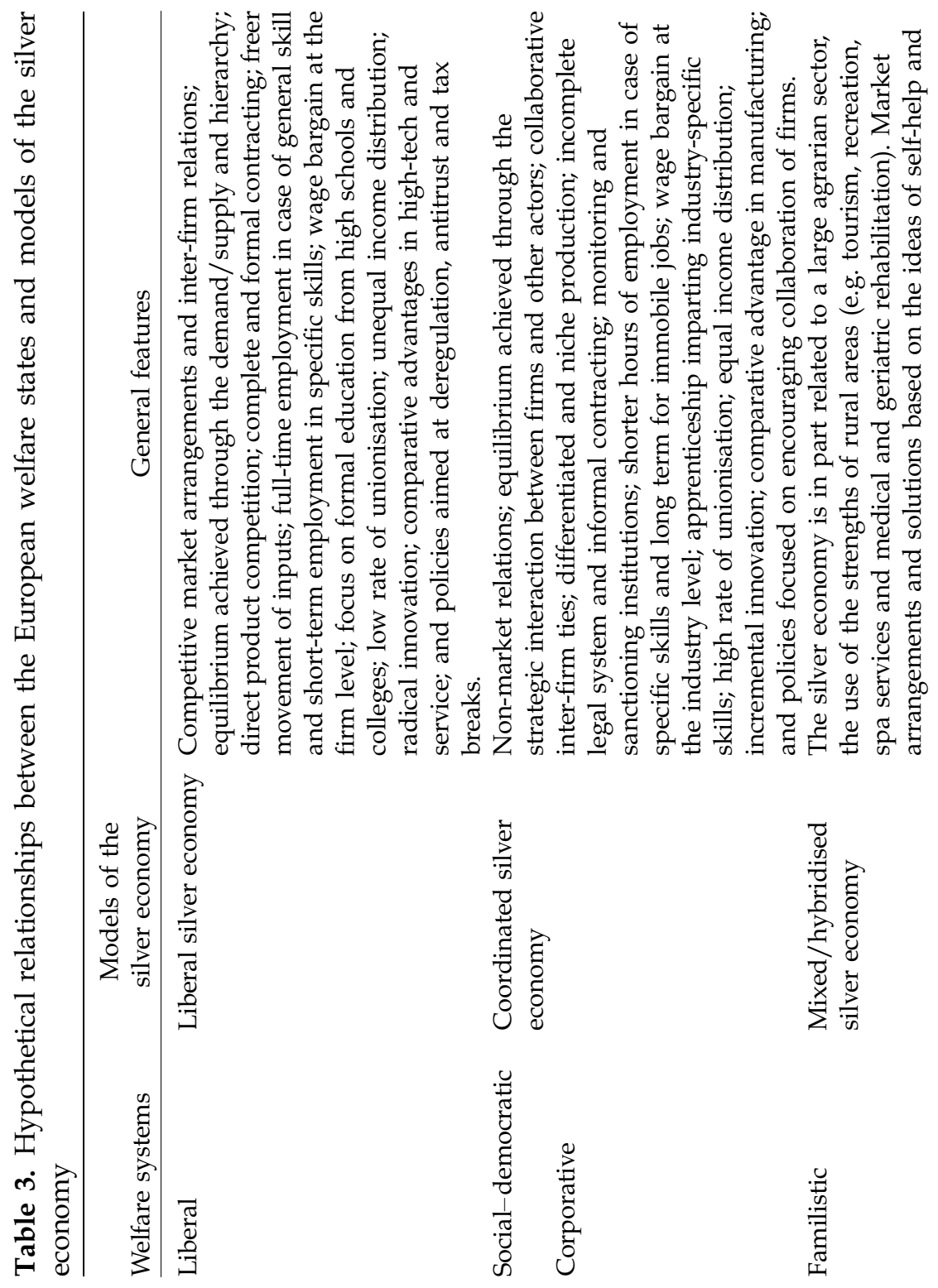


International Journal of Ageing and Later Life

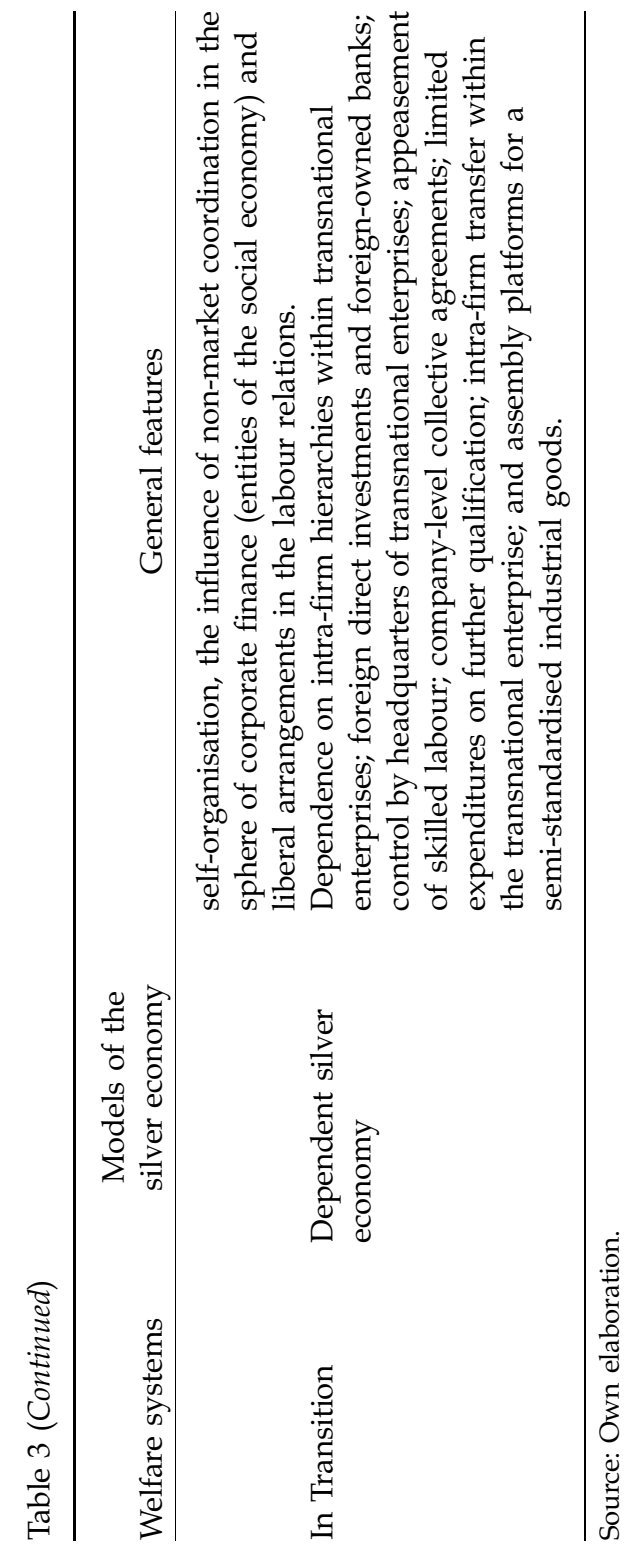


Comparative analysis of national and regional models

The findings of the study on "shrinking regions" created at the request of the European Parliament suggest that there are "two demographic Europes" with four sub-types of countries (Katsarova 2008: 18-19). "Shrinkage" is defined here not simply as depopulation but as a decline in the number of inhabitants of a particular city or region over the course of a generation (Katsarova 2008: iii). All the old member states of the EU (except Ireland) are characterised by a concentration of people aged 30-45 years and the growth in life expectancy. The countries of "west-old" (the Mediterranean region, Germany and Austria) are characterised by a decrease in the number of young people and insufficient immigration. The sub-type "west-young," includes the north-western regions with a lower decline of a young population and high level of immigration. In comparison, "east" countries of the EU (plus Ireland) are characterised mainly by age groups: $45-55$ and $20-35$. However, the young population is rapidly decreasing due to emigration to Western Europe. There is a subtype "east-old" (the Baltic States, Hungary, the Czech Republic and Bulgaria) and a sub-type "east-young" (Poland, Slovakia, Romania, Malta, Cyprus and Ireland) (Katsarova 2008: 18). Moreover, "east" countries and peripheral areas have more "shrinking regions," which tend to be significantly poorer than the average and are more dependent on transfer payments linked to direct regional aid, interpersonal solidarity and public investments in infrastructure and basic services (Katsarova 2008: 48-50). Shrinking regions are often characterised by agriculture, personal services and non-commercial activities or are former industrial areas (in Poland and Romania). Thus, such regions have fewer entities relevant to the development of R\&D for the silver economy. Exceptions are the shrinking areas of the western part of the contemporary Federal Republic of Germany and the Czech Republic.

Research results of the project Regions for All Ages supplement above observations (Ferry et al. 2006: 14-19). They also show the urban-rural polarisation in the EU. Most of the urban regions have a positive demographic development due to inward migration, which directs them to focus on the integration of migrants into the labour force and society. At this point, we may only highlight that some projects in the EU are already testing solutions and services based on ICTs that will support informal carers and migrant care assistants. Such solutions include, for example, 
International Journal of Ageing and Later Life

communication with the care recipient; online consultation on long-term care services; peer support (e.g. online forums); training on caregiving; and the use of ICTs, automation and robotics to enhance care functions (Carretero et al. 2012: 27-29). Thus, the silver economy may cover care systems that will integrate both gerontechnologies and migrant carers to support, for example, long-term care in home care and older adults with physical and/or cognitive disabilities. In contrast, rural regions tend to have a negative tendency (Ferry \& Vironen 2010: 4). The areas of liberal welfare states such as the United Kingdom and Ireland focus their policies mainly on the labour market, health care and reducing negative attitudes towards ageing. National-level strategies tend to have little influence on regional policies. The regions of social-democratic states focus on the antidiscrimination and flexible work arrangements for older adults, free counselling for companies in the field of ageing policy and institutional and financial resources for regions with dispersed settlements. The corporative regimes tend to focus on national reforms in the social insurance systems while the policies on a regional level are fragmented and lack coordination. The regions in familistic regimes focus on providing services, increasing the independence of older people and weakening incentives for early retirement. The regimes in transition focus on the restructuring of national economies. Thus, national and regional ageing policies gained importance in the European Year 2012 on Active Ageing and Solidarity between Generations. Moreover, case studies (Table 4) allow describing factors that contribute to effective implementation of regional interventions for an ageing population: political will and democratic legitimacy, preparing the ground and establishing a database, financial autonomy of local governments and agreement to evaluation (Ferry et al. 2006: 46-47). We may also add the high quality of human and social capital of change leaders, who are crucial for the development of the silver economy.

The research of the project 4 Leaf Clover Quality Model for Senior Service Sector confirms the above observations and adds that in the EU there are three types of social care systems (AMU Nordjylland 2009: 10-17). The social-democratic regimes are characterised by a variety of services, typically tax prepaid; the mixed model in the corporatist and liberal regimes have both public and private responsibility but the recruitment 
Comparative analysis of national and regional models

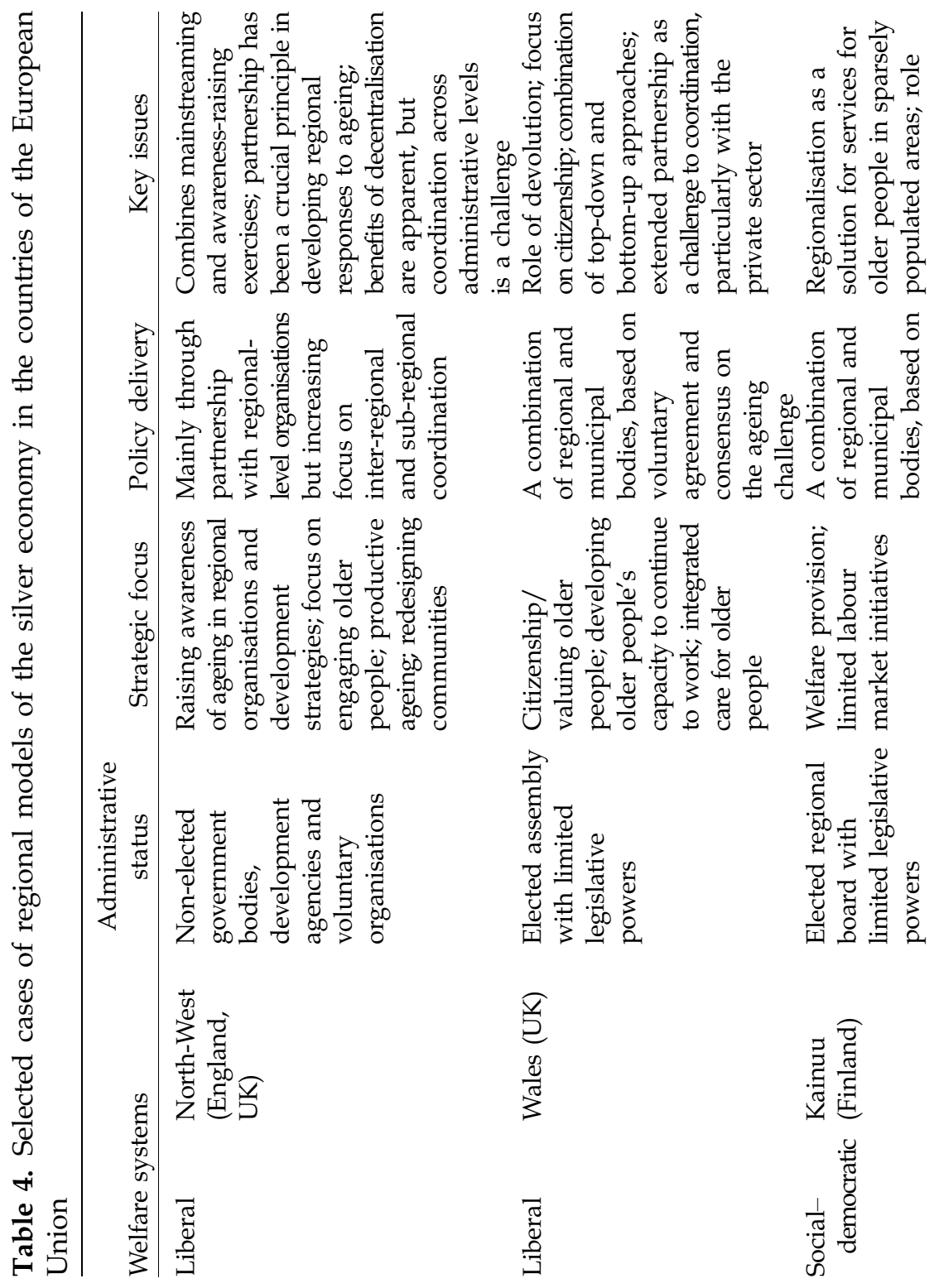


International Journal of Ageing and Later Life

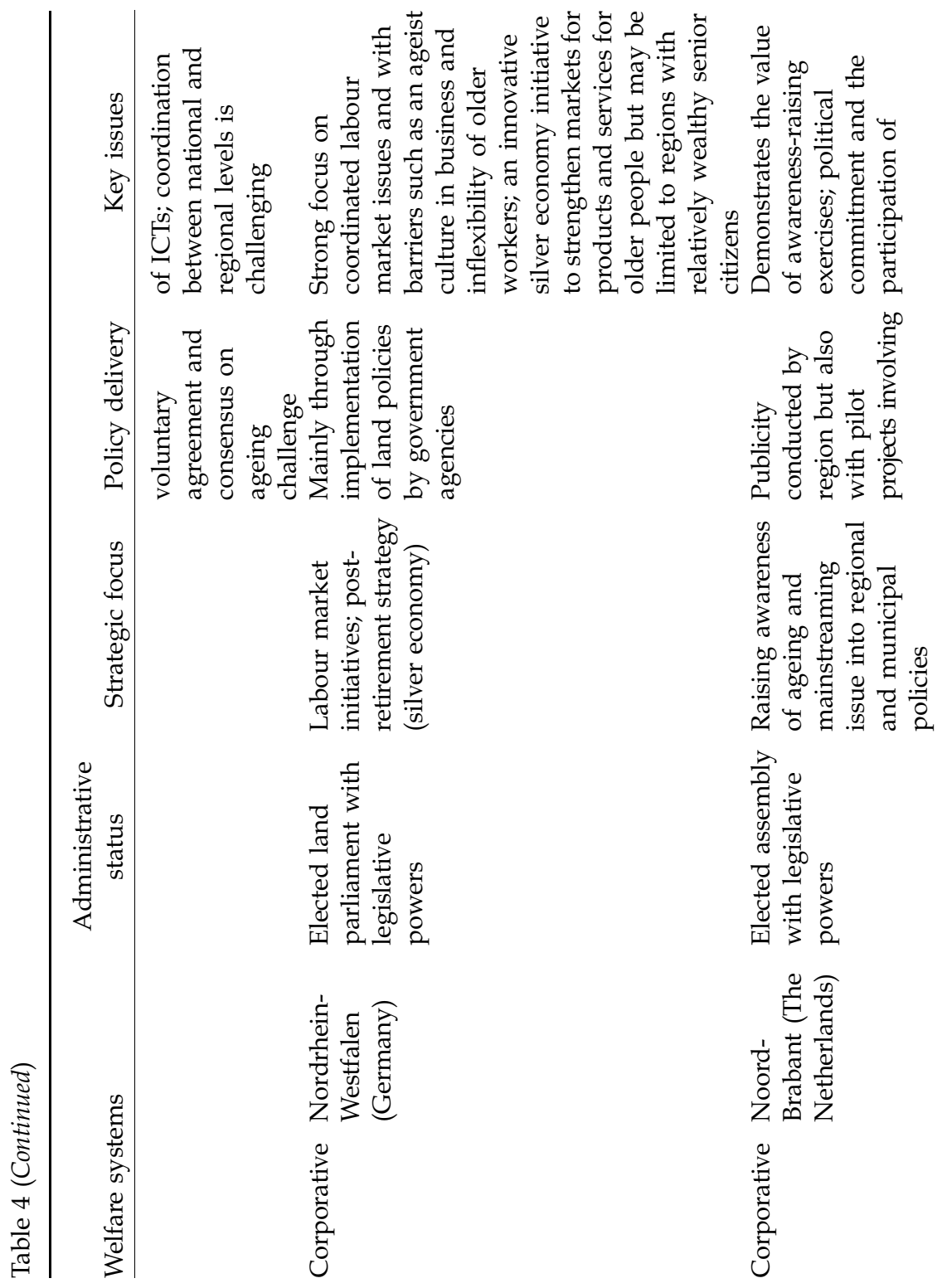


Comparative analysis of national and regional models

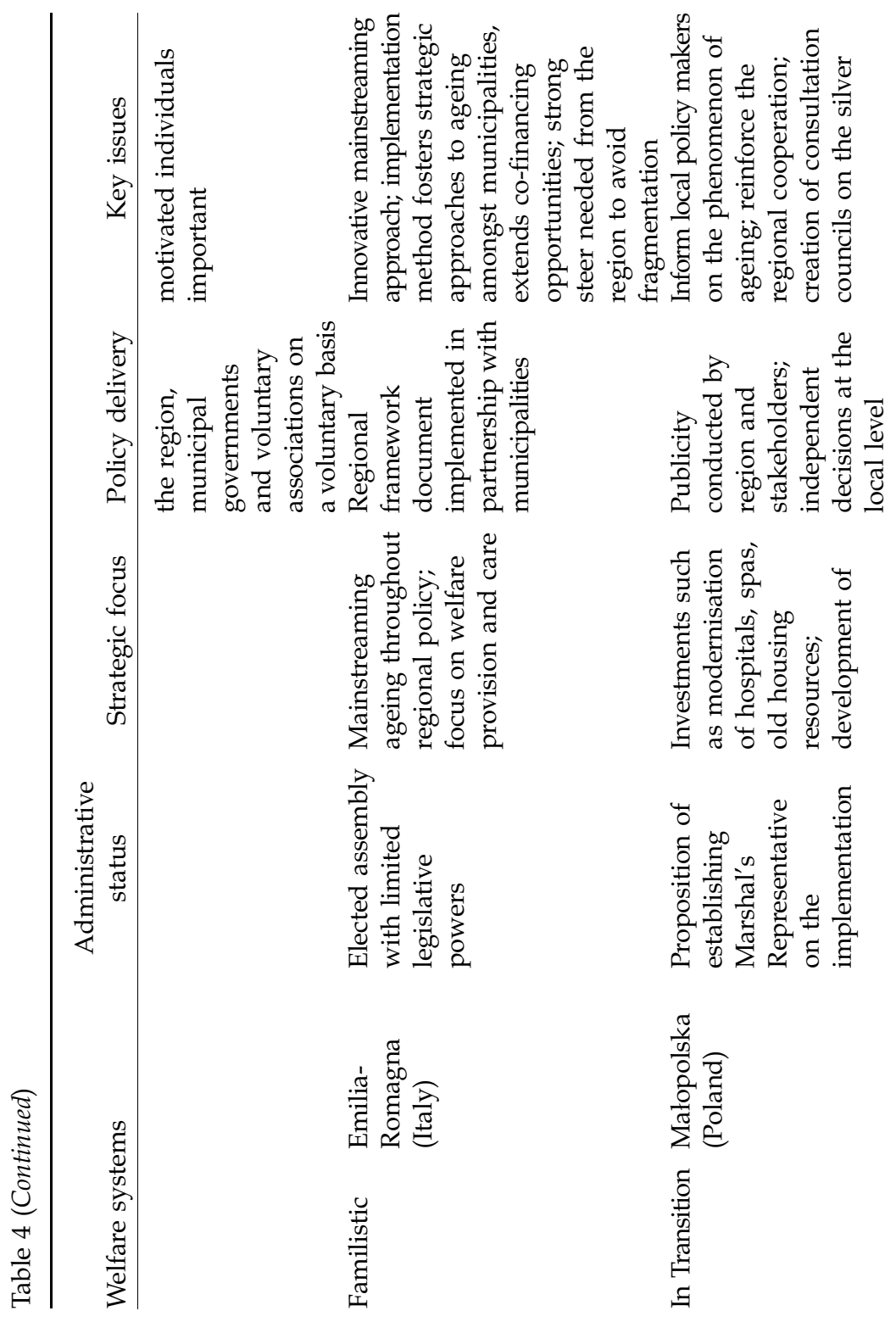


International Journal of Ageing and Later Life

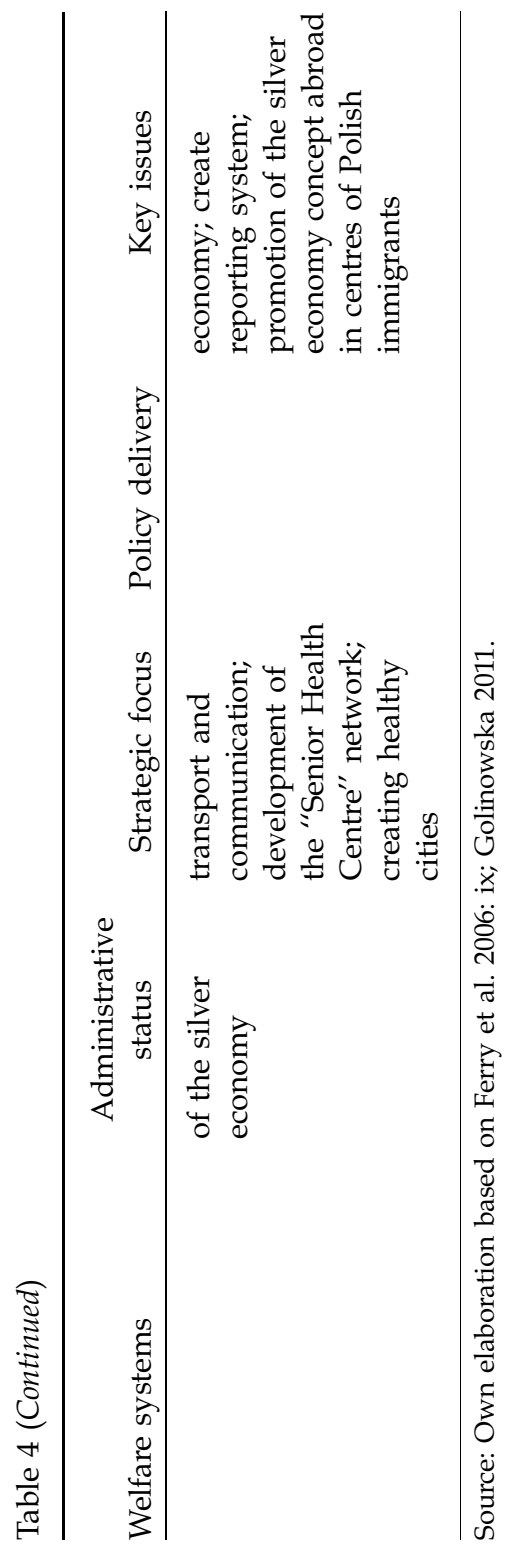


Comparative analysis of national and regional models

and education of carers are left to the free-market forces; and in the familistic and transition regimes, the minor focus is on the welfare system.

A central problem of care services in nearly all regions of the EU is the black labour market, which does not meet any legal standards of personnel training. The regions in liberal, social-democratic and corporative regimes tend to focus on fostering independent living, home care services, support services at home and the use of ICTs. Job profiles in the care field in these countries tend to mix traditional, systematic and professional tasks. The regions in familistic and transition regimes tend to focus on social networks, informal care and dividing the help and care tasks into different job profiles.

\section{Conclusions}

This article focuses on the possibility of using the AAI to explain the emerging differentiation of models of the silver economy in the EU countries. It presents the basic theoretical concepts associated with the silver economy and the implementation of the UN and the EU strategies for an ageing population. It also presents comparisons of the AAI to different clustering of countries and selected findings from case studies of regional models of the silver economies.

The conducted analysis allows us to formulate at least four practical recommendations for institutions engaged in ageing policy in the EU. First, further promotion of the silver economy in association with the creative economy as well as social and solidarity economy (Klimczuk 2015). Each of these economic systems supports and uses different forms of older people's capital. Respectively, the human capital corresponds to the silver economy, the cultural capital and the creative capital correspond to the creative economy and the social capital corresponds to the social and solidarity economy. However, none of these systems alone can meet the needs of ageing populations and so far only the silver economy was seen as related to challenges of ageing populations.

Second, the integration between mentioned economic systems may generate various socioe-conomic benefits such as technological innovation and social innovation for ageing societies (cf. O'Sullivan et al. 2010). Recent examples of such innovations include grants for relocation in Singapore so 
International Journal of Ageing and Later Life

that children can live near older parents and help them; age-friendly environments including specially designed benches and outdoor gyms for seniors available in various cities in the EU; smart mobile applications including software integrated into the operation and usage of smart homes and telehealth services; self-help groups for household repairs, exchange systems and time banks, such as "care tickets" in Japan; and Silver Human Resources Centres also in Japan that offer temporary jobs for older workers.

Third, the AAI may be extended by indicators on age discrimination, intergenerational relationships, acceptance of new technologies, R\&D in the field of ageing and patterns of consumption. The use of such indicators will allow further analysis of the silver economy and its variety including the development and implementation of smart specialisation strategies at the regional level.

Fourth, there is a need to foster the development of institutions specialising in the silver economy and their clusters (cf. Enste et al. 2008). As shown by the example of the "SEN@ER" network, the easy access of small- and medium-sized enterprises to experts in the field of ageing is crucial to identify potential business partners and establishment of offers to older consumers as well as to support and use the potential of older workers by the implementation of age management.

We can also propose at least six directions for further research: in-depth analysis of regional models of the silver economy, including their smart specialisation; the analysis of the silver economy in culturally diverse regions and shrinking regions; studies of migration policies and programmes related to older migrants; studies of the silver economy in the context of variety of mixed economies of welfare in the EU; studies of technology transfer and social innovation in the field of ageing; and examination of the development of potential international standards in the silver economy.

\section{Acknowledgements}

The early version of this article was presented at the International Seminar on Active Ageing Index held on April 16-17, 2015, at Brussels (Belgium), and received the honorary award as the highly commented paper. The seminar was organised by the United Nations Economic Commission for 
Comparative analysis of national and regional models

Europe (UNECE) and the European Commission's Directorate-General for Employment, Social Affairs and Inclusion (DG EMPL) in collaboration with the Oxford Institute of Population Ageing (OIPA).

\section{Corresponding Author}

Andrzej Klimczuk, Warsaw School of Economics, Aleja Niepodleglosci 162, 02-554 Warsaw, Poland. Email: klimczukandrzej@gmail.com

\section{References}

AbleData. (2016). Available on http://www.abledata.com (Accessed: February 20, 2016).

AMU Nordjylland. (2009). An ageing Europe: Challenges of the European Senior Service Sector: 4 leaf clover quality model for senior service sector project. Available on http://senior-service-sector.eu:8180/ opencms/export/sites/default/4LC/en/Results/NationalReports/WP2 TransantionalReportChallengesENG.pdf (Accessed: June 1, 2014).

Arts, W. \& Gelissen, J. (2006). Three worlds of welfare capitalism or more? A state-of-the-art report. In C. Pierson \& F. G. Castles (eds.), The Welfare State Reader (2nd ed., pp. 175-197). Cambridge: Polity.

Błędowski, P. (2012). Polityka wobec osób starych - cele i zasady [The policy towards older people - objectives and principles]. Studia BAS (2): 201-216.

Burdick, D. C. (2007). Gerontechnology. In J. E. Birren (ed.), Encyclopedia of Gerontology (pp. 619-630). Oxford: Academic Press.

Carretero, S., Stewart, J., Centeno, C., Barbabella, F., Schmidt, A., Lamontagne-Godwin, F. \& Lamura, G. (2012). Can technology-based services support long-term care challenges in home care? Analysis of evidence from social innovation good practices across the EU: CARICT Project Summary Report. Luxembourg: European Commission, Joint Research Centre.

Coulmas, F. (2008). Looking at the bright side of things. In F. Kohlbacher \& C. Herstatt (eds.), The Silver Market Phenomenon. Business Opportunities in an Era of Demographic Change (pp. v-vi). Berlin, Heidelberg: Springer.

Eatock, D. (2015). The silver economy: Opportunities from ageing. European Parliamentary Research Service Briefing, 1-8. 
Enste, P., Naegele, G. \& Leve, V. (2008). The discovery and development of the silver market in Germany. In F. Kohlbacher \& C. Herstatt (eds.), The Silver Market Phenomenon. Business Opportunities in an Era of Demographic Change (pp. 325-339). Berlin, Heidelberg: Springer.

Ervik, R. (2009). A missing leg of ageing policy ideas: Dependency ratios, technology and international organizations. Paper from ESPAnet conference, Urbino. Available on http://www.espanet-italia.net/ conference2009/paper/15 Ervik.pdf (Accessed: June 1, 2014).

Ervik, R. \& Lindén, T. S. (eds.). (2013). The Making of Ageing Policy: Theory and Practice in Europe. Cheltenham: Edward Elgar.

Esping-Andersen, G. (1990). The Three Worlds of Welfare Capitalism. Princeton, NJ: Princeton University Press.

European Commission. (2005). Communication from the Commission to the European Parliament, the council, the European economic and social committee and the committee of the regions - green paper confronting demographic change: A new solidarity between the generations: COM/2005/94. Brussels: European Commission.

European Commission. (2007). Europe's Demographic Future: Facts and Figures on Challenges and Opportunities. Luxembourg: Office for Official Publications of the European Communities.

European Commission. (2009). Communication from the Commission to the European Parliament, the council, the European economic and social committee and the committee of the regions - dealing with the impact of an ageing population in the EU (2009 Ageing Report): COM/ 2009/0180. Brussels: European Commission.

European Commission. (2011). Demography Report 2010: Older, more numerous and diverse Europeans. Luxembourg: Publications Office of the European Union.

European Commission. (2012). The EU contribution to active ageing and solidarity between generations. Luxembourg: Publications Office of the European Union.

European Commission. (2015a). European summit on innovation for active and healthy ageing, Brussels, 9-10 March 2015: Final Report. Brussels: European Commission.

European Commission. (2015b). Growing the silver economy in Europe: Background paper. Brussels: European Commission. 
Comparative analysis of national and regional models

Ferry, M., Novotný, V., Mancusi, V., Gross, T. \& Bachtler, J. (2006). Regions for all ages: The implications of demographic ageing for regional policy. Final Report. Glasgow: European Policies Research Centre; University of Strathclyde.

Ferry, M. \& Vironen, H. (2010). Dealing with demographic change: Regional policy responses. European Policy Research Paper (72): 1-30.

Foray, D., Goddard, J., Goenaga Beldarrain, X. \& Landabaso, M. (2012). Guide to research and innovation strategies for smart specialisation (RIS 3). Brussels: European Commission.

Golinowska, S. (ed.). (2011). Malopolskie Studia Regionalne. Challenges of Małopolska in the Context of an Aging Population. Cracow: Marshal Office of the Malopolska Region.

Hall, P. A. \& Soskice, D. W. (eds.). (2001). Varieties of Capitalism: The Institutional Foundations of Comparative Advantage. Oxford: Oxford University Press.

Hampden-Turner, C. \& Trompenaars, F. (2000). Building Cross-Cultural Competence: How to Create Wealth from Conflicting Values. New Haven, CT: Yale University Press.

Katsarova, I. (ed.). (2008). Shrinking Regions: A Paradigm Shift in Demography and Territorial Development. Study, IP/B/REGI/IC/2007-044 11/ 07/2008. Brussels: European Parliament.

Kazepov, Y. (2010). Rescaling social policies towards multilevel governance in Europe: Some reflections on processes at stake and actors involved. In Y. Kazepov (ed.), Rescaling Social Policies. Towards Multilevel Governance in Europe (pp. 35-72). Farnham: Ashgate.

Klimczuk, A. (2011). Strategic responses on population ageing in regional policy. In S. Hittmár (ed.), Theory of Management 4: The Selected Problems for the Development Support of Management Knowledge Base (pp. 261-265). Žilina: EDIS, University of Žilina.

Klimczuk, A. (2015). Economic Foundations for Creative Ageing Policy, Volume I: Context and Considerations. New York: Palgrave Macmillan.

Lavelle, A. (2008). The Death of Social Democracy: Political Consequences in the 21st Century. Farnham: Ashgate Publishing.

Lindbom, A. (2001). Dismantling the social democratic welfare model? Has the Swedish welfare state lost its defining characteristics? Scandinavian Political Studies 24(3): 171-193. 
International Journal of Ageing and Later Life

Ministry of Education, Culture, Sports, Science and Technology, Japanese Government. (2006). White paper on Science and Technology 2006. Challenges for Building a Future Society: The Role of Science and Technology in an Aging Society with Fewer Children. Tokyo: Ministry of Education, Culture, Sports, Science and Technology, Japanese Government.

Moody, H. R. \& Sasser, J. R. (2012). Aging: Concepts and Controversies (7th ed.). Thousand Oaks, CA: Sage.

Nölke, A. \& Vliegenthart, A. (2009). Enlarging the varieties of capitalism: the emergence of dependent market economies in East Central Europe. World Politics 61(04): 670-702.

O'Sullivan, C., Mulgan, G. \& Vasconcelos, D. (2010). Innovating Better Ways of Living in Later Life: Context, Examples and Opportunities. Working Paper/The Young Foundation May, 1-38.

Sen, A. (2009). The Idea of Justice. London: Penguin.

SEN@ER. (2014). Available on http://www.silvereconomy-europe.org (Accessed: June 1, 2014).

Szatur-Jaworska, B. (2006). Dwa aspekty polityki spolecznej - polityka wobec ludzi starych i polityka wobec starosci [Two aspects of social policy - Policy Towards older people and policy towards old age]. In B. Szatur-Jaworska, P. Błdowski, \& M. Dzięgielewska (eds.), Podstawy Gerontologii Spolecznej [Fundamentals of Social Gerontology] (pp. 291-294). Warszawa: ASPRA-JR.

UNECE. (2012). Synthesis Report on the Implementation of the Madrid International Plan of Action on Ageing in the UNECE Region: Second Review and Appraisal of the Regional Implementation Strategy of the Madrid Plan of Action on Ageing (MIPAA/RIS). Geneva: UNECE.

UNECE. (2014). AAI Results for EU28: 2010 AAI. Available on http:// www1.unece.org/stat/platform/download/attachments/76287845/ 2010 AAI_Results_5th_December_EU28only.xlsx (Accessed: April 27, 2015).

WHO. (2002). Active Ageing: A Policy Framework. Geneva: WHO.

Zaidi, A. Policy Brief: AAI 2014: Active ageing index for 28 European Union Countries. Available on http://www1.unece.org/stat/platform/ download/attachments/76287849/Policy_Brief_AAI_2014_November2014_ FINAL.PDF (Accessed: January 14, 2015). 
Zaidi, A., Gasior, K., Hofmarcher, M. M., Lelkes, O., Marin, B., Rodrigues, R., Schmidt, A., Vanhuysse, P. \& Zolyomi, E. (2013). Active Ageing Index 2012: Concept, Methodology and Final Results: Methodology Report Submitted to European Commission's DG Employment, Social Affairs and Inclusion, and to Population Unit, UNECE, for the project: Active Ageing Index (AAI). Geneva: UNECE. Available on http:// www1.unece.org/stat/platform/download/attachments/76287849/ Methodology-Paper Final.pdf (Accessed: January 14, 2015).

Zaidi, A. \& Stanton, D. (2015). Active Ageing Index 2014: Analytical Report. Available on http://www1.unece.org/stat/platform/download/ attachments/76287849/AAI Report LOW RES.PDF (Accessed: April 20, 2015). 